DOI: https://doi.org/10.11144/Javeriana.upsy20.ilwe

\title{
Identity Leadership and Work Engagement in Spain: A Cross-Cultural Adaptation of the Identity Leadership Inventory*
}

\section{Liderazgo basado en la identidad y work engagement en España: Una adaptación transcultural del Inventario de Liderazgo Identitario (ILI)}

\author{
Ana Laguía a \\ Universidad Nacional de Educación a Distancia (UNED), Spain \\ ORCID: https://orcid.org/0000-0002-4634-3127 \\ JuAn A. Moriano \\ Universidad Nacional de Educación a Distancia (UNED), Spain \\ ORCID: https://orcid.org/0000-0002-8332-1314 \\ FERnANDo Molero \\ Universidad Nacional de Educación a Distancia (UNED), Spain \\ ORCID: https://orcid.org/0000-0001-9789-9822 \\ Cristina García-Ael \\ Universidad Nacional de Educación a Distancia (UNED), Spain \\ ORCID: https://orcid.org/0000-0002-9460-9268 \\ ROLF VAN Dick \\ Goethe University Frankfurt, Germany \\ ORCID: https://orcid.org/0000-0002-6308-9466
}

a Correspondence author. Email:
aglaguia@psi.uned.es

How to cite: Laguía, A., Moriano, J. A., Molero, F., García-Ael, C., \& van Dick, R. (2021). Identity leadership and work Engagement in Spain: A CrossCultural Adaptation of the Identity Leadership Inventory. Universitas Psychologica, 20, 1-13. https:// doi.org/10.11144/Javeriana.upsy20.ilwe

\begin{abstract}
This paper reports the adaptation and validation of the Identity Leadership Inventory (ILI) in a Spanish organizational context. In addition, this study empirically explores the positive relationship between identity leadership and followers' work engagement as mediated by positive and negative job-related affect. A total of 854 employees from different organizations $(53.6 \%$ female, $46.4 \%$ male; $M=40.7$ years, SD $=11.5,19-74)$ completed an online questionnaire. Descriptive analyses, as well as confirmatory factor analyses, were conducted. According to our results, the Spanish version of the ILI had adequate psychometric properties. The four dimensions obtained in other countries (i.e., identity prototypicality, identity advancement, identity entrepreneurship, and identity impresarioship) were replicated in our sample. Moreover, we found that only identity entrepreneurship significantly related to followers' positive and negative affect at work, which in turn, related to reported work engagement. We conclude that the Spanish version of the ILI adequately measures identity leadership in organizations. Future studies can build on this instrument to assess and foster identity leadership among supervisors.
\end{abstract}

Keywords

leadership; social identity; positive affect; work engagement; Identity Leadership Inventory. 


\section{RESUMEN}

Este artículo describe la adaptación y validación del Identity Leadership Inventory (ILI) en contextos organizacionales en España. Asimismo, este estudio explora empíricamente la relación positiva entre este estilo de liderazgo y el work engagement de los seguidores, mediada por el afecto positivo y negativo en el trabajo. Un total de 854 empleados $(53.6 \%$ mujeres, $46.4 \%$ hombres; $M=$ 40.7 años, $S D=11.5,19-74)$ cumplimentaron un cuestionario online. Se realizaron análisis descriptivos y factoriales confirmatorios. Los resultados indicaron que la versión española del ILI presenta adecuadas propiedades psicométricas. Las cuatro dimensiones obtenidas en otros países (prototipicidad de la identidad, promoción de la identidad, emprendimiento de la identidad y establecimiento de la identidad) fueron replicadas en nuestra muestra. Únicamente el emprendimiento de la identidad se relacionó significativamente con el afecto positivo y negativo en el trabajo de los seguidores, los cuales, a su vez, se relacionaron con el engagement reportado. Concluimos, por tanto, que la versión española del ILI mide adecuadamente el liderazgo en las organizaciones desde la perspectiva de la identidad social. Futuros estudios se pueden apoyar en este instrumento para valorar y promover este estilo de liderazgo.

Palabras clave

liderazgo; identidad social; afecto positivo; work engagement; Inventario de Liderazgo Identitario.

The social identity approach to leadership has attracted increasing attention in the last decade (Epitropaki et al., 2017; Steffens, Haslam, Kerschreiter et al., 2014; van Dick \& Monzani, 2020). According to this approach, leadership is considered a psychological group process of social influence. The development of a measurement inventory, the Identity Leadership Inventory (ILI; Steffens, Haslam, Reicher, et al., 2014), has provided a useful tool for researchers and practitioners, allowing them to assess different facets of leaders' identity management. The availability of a sound inventory paves the ground to explore how these facets relate to relevant organizational outcomes. Indeed, identity leadership as perceived by employees has been related to important indicators of leadership effectiveness (Steffens, Haslam, Kerschreiter, et al., 2014; Steffens, Haslam, Reicher, et al., 2014; Steffens et al., 2018; van Dick et al., 2018), such as employees' relationship to their team (identification, confidence, and perceived team support) and to their leader (trust and perceived influence), as well as employees' wellbeing (job satisfaction, reduced burnout, and increased work engagement) and performance (task cohesion, organizational citizenship, and innovative behavior at work). However, further empirical research is needed to acquire a greater understanding of the different facets of identity leadership in various cultural contexts and how these facets relate to followers' outcomes.

The ILI has been validated in more than 20 countries (including one Spanish-speaking country, Chile) and in different contexts through diverse samples (Steffens, Haslam, Reicher, et al., 2014; van Dick et al., 2018). Our aim in this study is twofold: to validate the ILI in Spain on a sample of employees and to explore the extent to which the ILI relates to followers' work engagement. Moreover, we propose a model whereby positive and negative job-related affect might mediate the association between ILI facets and work engagement.

\section{Conceptual framework}

\section{The social identity approach to leadership and followership}

The social identity model of leadership is one of the most important paradigms in the grouplevel leadership analysis (Epitropaki et al., 2017). This social identity approach draws on two theories, social identity theory (Tajfel \& Turner, 1979) and self-categorization theory (e.g., Turner et al., 1987), which have generated extensive research in the social psychology field (Hogg et al., 2004). From this perspective, leadership is considered a psychological group process of social influence structured by people's shared group membership (Haslam et al., 2017; Platow et al., 2015). This process “centers on leaders' capacities to represent, advance, create, and embed a shared sense of social identity for group members" (Steffens, Haslam, Reicher, et al., 2014, p. 1002). To this extent, leaders are expected to be more successful if they provide group-oriented leadership regarding a shared social identity (van Dick \& Kerschreiter, 2016). 
According to this approach, leadership should only be understood within the context of a specific group (Epitropaki et al., 2017). Shared psychological group membership is considered the key mediating process through which leadership develops (Platow et al., 2015). Leaders create and foster a shared sense of "us" (Steffens, Haslam, Reicher, et al., 2014), channeling followers' coordinated energies to contribute to shared goals and enable meaningful forms of group behavior.

\section{Dimensions of identity leadership}

To mobilize and direct followers' energies, leaders must comply with not only identity prototypicality ("be one of us") but also three other dimensions (Platow et al., 2015; Steffens, Haslam, Reicher, et al., 2014): identity advancement (leaders need to "do it for us"), identity entrepreneurship (leaders need to "craft a sense of us"), and identity impresarioship (leaders need to "make us matter"). The ILI was developed by Steffens, Haslam, Reicher, et al. (2014) to assess followers' perceptions of their leaders' identity management in these four dimensions. Its practical value lies in measuring processes in ongoing groups (Platow et al., 2015). Steffens, Haslam, Reicher, et al. (2014) strongly recommend using the scale to separately examine each dimension rather than a single superordinate identity leadership factor. By assessing these multiple dimensions of leaders' social identity management, the ILI enables an exploration of the role these different facets play in the leadership process and predicting relevant outcomes.

Prototypicality in the ILI notably deals with what it means to be a member of the group beyond simply "being similar" to other members or an "average" thereof (for a meta-analytic review of prototypicality within the social identity theory, see Steffens et al., 2020). The other three more novel dimensions focus on the degree to which leaders not only represent the unique qualities that define the group but also advance, create, and embed a sense of shared social identity among followers (i.e., a sense of "us"). These separate aspects of identity management are thought to help leaders convey their vision for the group (van Dick \& Kerschreiter, 2016). Leaders, therefore, achieve a stronger identity when they: a) make clear their vision for the group and put themselves at its center; b) champion their vision; c) actively manage the group's identity; and $\mathrm{d}$ ) device activities and structures that bring the group together, helping followers experience a collective identity.

The newly developed and validated ILI assesses followers' perceptions of their leaders in these four dimensions and allows for a deeper understanding of the relationship between these dimensions and followers' motivations and outcomes. A growing body of empirical evidence shows that each facet is relevant to effective leadership and has a unique impact (e.g., Steffens, Haslam, Kerschreiter, et al., 2014; Steffens et al., 2013; Steffens et al., 2018; van Dick et al., 2018). For instance, team members' perceived team support, work engagement, task cohesion, and innovation are predicted by leaders' identity entrepreneurship and identity impresarioship (Steffens, Haslam, Reicher et al., 2014; van Dick et al., 2018). Additionally, leaders' identity prototypicality has been found to predict perceived leader influence (Steffens, Haslam, Reicher, et al., 2014). The four facets are related to job satisfaction, team identification, or trust (van Dick et al., 2018), although to varying extents.

\section{Hypothesis development}

\section{Structure of the ILI}

The ILI was developed in three phases (Steffens, Haslam, Reicher, et al., 2014). First, the inventory items were generated from a detailed review of the literature, and items within each facet were discussed and refined through several iterations. Twenty items were selected after feedback was collected from social and organizational psychologists on their construct 
clarity and comprehensibility. Second, a sample of non-expert participants was asked to read the theoretical definition of each dimension and assess the extent to which each related item appeared to represent it. The 16 items with the clearest dimensionality were then subjected to an extended data matrix factor analysis and a principal-axis factor analysis. Third, construct validity was established by showing that a 15 -item ILI had an adequate factorial structure based on confirmatory factor analyses on samples from different countries.

Additionally, discriminant validity was established by showing that the four ILI dimensions can be differentiated from other close leadership styles (e.g., authentic leadership, leaders' idealized influence, and perceived leader quality). Each dimension is unrelated to another psychological construct, such as self-esteem. Furthermore, criterion validity was established by showing that the four dimensions differentially predicted relevant outcomes such as job satisfaction, team identification, work engagement, and perceived team support in the context of both organizations and sports. Since then, the ILI has been validated in 20 countries/ regions, and 14 different languages by van Dick et al. (2018), showing that both a four-correlatedfactors model and a higher-order construct of identity leadership are based on four dimensions fit the data well.

In accordance with previous research, we formulated the following hypothesis:

H1. The structure of the ILI will involve four factors: identity prototypicality, identity advancement, identity entrepreneurship, and identity impresarioship. These factors will show sufficient reliability.

\section{Validity}

We also examine the criterion validity of the Spanish version of the ILI. We focus on employees' positive and negative affect, as well as on work engagement.

Work engagement. We take employees' work engagement to be a key indicator of well- being in the workplace (Steffens et al., 2017). A vast literature shows that employees' wellbeing at work is related to their perception of their superiors' particular leadership style (for a review, see Arnold, 2017; Skakon et al., 2010), such as transformational leadership (Arnold, 2017), authentic leadership (Azanza et al., 2018), or security-providing leadership (Molero et al., 2019). Moreover, positive leader behaviors are associated with high employee well-being (Skakon et al., 2010). In particular, social identity and self-categorization processes contribute to employees' well-being (Haslam \& van Dick, 2012; van Dick \& Kerschreiter, 2016). Shared identity helps interpret potential stressors (primary appraisal) and cope with them (secondary appraisal) in a positive way (Haslam \& van Dick, 2012). While most studies within the social approach have focused on stress and burnout (Haslam \& van Dick, 2012; van Dick et al., 2018), further research is needed to understand a related, opposite concept better: work engagement (Schaufeli et al., 2017), to add some insights to the yet scarce literature on this positive aspect of the job (Robledo et al., 2019; Steffens, Haslam, Kerschreiter, et al., 2014; Villajos et al., 2019). Steffens, Haslam, Reicher, et al. (2014) hypothesized that employees would show greater work engagement to the extent that: a) the team engaged in job crafting by actively shaping the work environment, and b) leaders embedded structures related to shared group membership. They found that leaders' identity impresarioship and identity entrepreneurship had a significant positive impact on respondents' work engagement. In contrast, leaders' perceived identity prototypicality and identity advancement had a non-significant impact on work engagement. Based on this literature, we formulate the following hypothesis:

H2. Leader identity facets will be positively related to followers' work engagement.

Job-related affect. We further propose a model whereby employees' perception of their leaders' identity leadership enhances their positive affect and decreases their negative affect at work, 
which in turn increases their work engagement. Given that social identity processes are guided by self-enhancement and uncertainty reduction (Hogg et al., 2004) and that leaders are considered to constitute sources of positive and negative emotions for employees at work (Arnold, 2017), we argue that an adequate social identity leadership management can foster followers' positive affect and reduce their negative affect. Moreover, according to the affective shift model of work engagement (Bledow et al., 2011), both positive and negative affect substantially impact work engagement, which is an affective-motivational state. Both positive and negative affectivity has been shown to have considerable effects on burnout and work engagement (Castellano et al., 2019).

Previous studies have shown that followers' negative and especially positive affect at work mediates the relationship between leadership styles and relevant organizational outcomes, such as employee burnout (e.g., Molero et al., 2019) or innovation (Zhou et al., 2014). Drawing on these findings, we establish the following hypothesis:

H3a. Followers' increased positive affect will mediate the positive relationship between leader identity facets and followers' work engagement.

$\mathrm{H} 3 b$. Followers' reduced negative affect will mediate the positive relationship between leader identity facets and followers' work engagement.

\section{Methods}

\section{Sample}

Our sample consisted of 854 employees $(53.6 \%$ female; $46.4 \%$ male), with an average age of 40.7 years $(S D=11.5,19-74)$, from different organizations located in Madrid (29.9\%), Andalusia (15.2\%), the Valencian Community (8.9\%), Catalonia (5.7\%), and Aragon (5\%). Most participants held a university degree (56\%) or had finished vocational training (18.4\%); $15.8 \%$ reported secondary studies, $4.8 \%$ primary studies, and $5 \%$ other studies. The majority of respondents worked in a private company (65.4\%), followed by those working in a public office (29.2\%) and other types of organizations $(5.4 \%)$. These organizations were categorized as large (more than 250 employees, $47.6 \%$ ), smallto-medium (10 to 250 employees, 38\%), and micro (less than ten employees, 14.5\%). The majority of supervisors were male $(58.9 \%$; $41.1 \%$ female) aged 41 to $55(55.6 \% ; 26.9 \%$ aged 25 to $40 ; 17.4 \%$ aged over 55). Participants worked in the same team for an average of 6 years $(S D=$ $6.9,0-39)$.

\section{Measures}

The questionnaire we used in this study consists of the following sections.

Identity leadership. We used the 15-item ILI (Steffens, Haslam, Reicher, et al., 2014). All items refer to participants' immediate supervisor. Four items focus on leader identity prototypicality (e.g., “... embodies what the group stands for"), four items measure identity advancement (e.g., "... promotes the interests of members of the group"), four items concern identity entrepreneurship (e.g., "... creates a sense of cohesion within the group"), and the three remaining items measure identity impresarioship (e.g., "... devices activities that bring the group together"). We used a sevenpoint Likert-type response format ranging from 0 (not at all) to 6 (completely). This inventory has been translated into Spanish and validated in Chile (van Dick et al., 2018); we made some minor linguistic modifications to adapt it to the Spanish spoken in Spain (see Table 1).

Job-related affective well-being. We used the Spanish version of the 12-item Warr's scale (Laguna et al., 2017). This instrument, widely used in work contexts, consists of two factors: positive affect (calm, contented, relaxed, cheerful, enthusiastic, and optimistic) and negative affect (tense, uneasy, worried, depressed, gloomy, and miserable). Participants were asked to indicate how frequently they had experienced these emotions at work in the last weeks $(0=$ never to $6=$ always $)$.

Work engagement. We used the three-item scale of Schaufeli et al. (2017). Participants responded 
to all items (e.g., "At my work, I feel bursting with energy") on a seven-point scale from 0 (never) to 6 (every day).

Sociodemographic and control variables. We included a set of control variables related to participants (i.e., gender, age, educational level, time working with a supervisor, and time working with the team), their organizations (e.g., type, size, and activity sector), and their supervisors (gender and age).

\section{Procedure}

Undergraduate psychology students recruited participants at a Spanish university in exchange for academic credit. Each student contacted at least four participants and gave them general instructions for completing the online questionnaire. The questionnaire was designed using the Qualtrics survey platform (https://ww w.qualtrics.com), which guarantees anonymity. The study followed the recommendations of the UNED Ethics Committee. Informed consent was shown on the initial page of the online questionnaire (those who declined were redirected to the end of the questionnaire and did not complete any of the measures). Participants could withdraw from the study whenever they wanted. On average, it took participants approximately 15 minutes to answer it $(S D=13.9)$.

\section{Data analysis}

First, we conducted confirmatory factor analysis (CFA) to identify factor loadings and goodnessof-fit indices for the ILI, using EQS 6.3 software for Windows (Bentler, 2006; Bentler \& $\mathrm{Wu}, 2015)$. We selected the robust maximum likelihood estimation method, which provides approximations of the errors and adjustment statistics in the presence of deviations from the multivariate normality assumption (Brown, 2015). To evaluate the model's goodness-offit, we applied the Satorra-Bentler scaled chisquare $(\mathrm{S}-\mathrm{B} \times 2)$ test; non-significant values $(p$ $>0.05)$ and a result under 2 when dividing
S-B $\chi^{2}$ by the degrees of freedom verify the proposed model's adjustment to the data. Due to the $\chi^{2}$ statistic's sensitivity to sample size, we considered other indices to evaluate model fit, such as the root mean square error of approximation (RMSEA), the comparative fit index (CFI), and the non-normed fit index (NNFI). An acceptable adjustment should have CFI values over 0.95 and NNFI values over 0.90 (perfect adjustment corresponds to a value of 1), and RMSEA values around 0.05 (values of about 0.08 or less indicate a reasonable error of approximation to the population, while values over 0.10 indicate an inadequate approximation). In addition to these indices, we selected the Akaike information criterion (AIC) for model comparisons, according to which the model with the lowest value is considered the most adequate.

Furthermore, we calculated means, standard deviations, reliabilities (Cronbach's alphas), and Pearson's correlations using SPSS. Finally, we estimated the predictive validity of the ILI facets using EQS 6.3.

\section{Results}

\section{Descriptive analysis}

First, all 15 items showed acceptable asymmetry and kurtosis across the sample (Table 1). Mean values ranged from $\mathrm{M}=2.84$ (ILI 13... [My immediate supervisor...] devices activities that bring the group together) to $\mathrm{M}=3.68$ (ILI 7... [My immediate supervisor] stands up for the group). 
Table 1

Mean, standard deviation, asymmetry, and kurtosis of the 15-item Identity Leadership Inventory (ILI)

\begin{tabular}{|c|c|c|c|c|c|}
\hline & Item & $M$ & $S D$ & Skewness & Kurtosis \\
\hline & $\begin{array}{l}\text { Personifica lo que el grupo representa } \\
\text { [... embodies what the group stands for] }\end{array}$ & 3.59 & 1.73 & -0.51 & -0.53 \\
\hline & $\begin{array}{l}\text { Es representativo/a de los miembros del grupo } \\
\lceil\ldots \text { is representative of members of the group }]\end{array}$ & 3.54 & 1.77 & -0.43 & -0.76 \\
\hline & $\begin{array}{l}\text { Es un miembro modelo del grupo } \\
\text { [... is a model member of the group] }\end{array}$ & 3.42 & 1.86 & -0.37 & -0.94 \\
\hline & $\begin{array}{l}\text { Ejemplifica lo que significa ser miembro del grupo } \\
\text { [... exemplifies what it means to be a member of the group] }\end{array}$ & 3.50 & 1.81 & -0.41 & $-0.8=$ \\
\hline & $\begin{array}{l}\text { Promueve los intereses de los miembros del grupo } \\
\text { [... promotes the interests of members of the group] }\end{array}$ & 3.71 & 1.79 & -0.54 & -0.72 \\
\hline & ulsor (o una impulsora) del & 3.71 & 1.81 & -0.51 & -0.77 \\
\hline & the group] & 3.98 & 1.80 & -0.67 & $-0.5 ?$ \\
\hline & $\begin{array}{l}\text { Tiene los intereses del grupo presentes cuando actúa } \\
\text { [... has the group's interests at heart when he or she acts] }\end{array}$ & 3.76 & 1.78 & -0.47 & -0.81 \\
\hline & $\begin{array}{l}\text { Hace sentir a la gente que son parte del mismo grupo } \\
\text { 「... makes people feel as if they are part of the same group }\end{array}$ & 3.76 & 1.84 & -0.51 & $-0.8=$ \\
\hline & $\begin{array}{l}\text { Crea una sensacion de cohesión dentro del grupo } \\
\text { [... creates a sense of cohesion within the group] }\end{array}$ & 3.51 & 1.85 & -0.33 & -0.96 \\
\hline & $\begin{array}{l}\text { Desarrolla un entendimiento de lo que significa ser parte } \\
\text { del grupo [... develops an understanding of what it means } \\
\text { to be a member of the group] }\end{array}$ & 3.47 & 1.79 & -0.34 & -0.91 \\
\hline & $\begin{array}{l}\text { Moldea las percepciones de los miembros sobre los valores } \\
\text { e ideales del grupo [... shapes members' perceptions of the } \\
\text { group's values and ideals] }\end{array}$ & 3.31 & 1.72 & -0.31 & -0.81 \\
\hline & $\begin{array}{l}\text { Genera actividades que unen al grupo } \\
\text { [... devices activities that bring the group together] }\end{array}$ & 2.84 & 1.84 & -0.01 & -1 \\
\hline & $\begin{array}{l}\text { Coordina eventos que ayudan a que el grupo funcione con } \\
\text { eficacia [... arranges events that help the group function } \\
\text { effectively] }\end{array}$ & 2.92 & 1.84 & -0.03 & -1.02 \\
\hline & $\begin{array}{l}\text { Crea estructuras que son útiles para los miembros del grupo } \\
\text { [... creates structures that are useful for group members] }\end{array}$ & 3.21 & 1.79 & -0.20 & -0.92 \\
\hline
\end{tabular}

Note. $N=854$. Scores could range between 0 and 6 .

Factorial structure of the ILI - Confirmatory factor analysis (CFA)

To test the ILI's factorial structure, we compared our proposed four-factor model (Model 1) with an alternative one-factor model with all items loading onto a single factor (Model 2) and a model whereby four first-order factors contribute to a superordinate second-order factor (Model 3). Table 2 illustrates fit indices. The model fit was much better for Models 1 and 3 than for Model 2; in Models 1 and 3, both CFI and NNFI values were higher, while RMSEA and AIC values were lower, showing better adjustment. Thus, the CFA results confirmed the validity of the ILI's original four-factor structure in Spanish. Differences between Models 1 and 3 were minor, but Model 1 appeared to fit slightly better. These results support $\mathrm{H} 1$.
Table 2

Indices of adjustment and comparison among alternative models

\begin{tabular}{|c|c|c|c|c|c|c|c|}
\hline Model & S-B $\chi^{2}$ & $d f$ & $p$ & CFI & NNFI & RMSEA & AIC \\
\hline $\begin{array}{l}\text { Model 1: } 4 \text { correlated } \\
\text { factors }\end{array}$ & 378.05 & 84 & $<0.001$ & 0.98 & 0.98 & 0.06 & 210.06 \\
\hline Model 2: 1 factor & 1248.34 & 90 & $<0.001$ & 0.92 & 0.91 & 0.12 & 1068.34 \\
\hline $\begin{array}{l}\text { Model 3: } 4 \text { factor and } \\
\text { a higher-order factor }\end{array}$ & 382.66 & 86 & $<0.001$ & 0.98 & 0.98 & 0.06 & 210.66 \\
\hline
\end{tabular}

Table 3 shows that all factor loadings were 0.70 or higher (Hair et al., 2006). Convergent validity, measured by the average variance extracted (AVE), represents the common variance between indicators and their construct (Fornell \& Larcker, 1981). The AVE values obtained, all over 0.50 , revealed adequate convergent validity (Table 3 ). To assess internal consistency, we calculated Cronbach's alphas and composite reliability for each of the four factors and the 15-item scale as a whole. All coefficients exceeded the cut-off value of 0.70 (Table 3). These results provide additional support to $\mathrm{H} 1$. 
Table 3

Factor loadings, reliability, and average variance extracted (AVE) for each of the four ILI facets

\begin{tabular}{|c|c|c|c|c|c|}
\hline Factor & Item & $\lambda$ & $\begin{array}{l}\text { Cronbach's } \\
\text { alphas }\end{array}$ & $\begin{array}{l}\text { Composite } \\
\text { reliability }\end{array}$ & AVE \\
\hline \multirow{5}{*}{ F1-Prototypicality } & & & 0.95 & 0.89 & 0.67 \\
\hline & ILI 1 & 0.89 & & & \\
\hline & ILI 2 & 0.9 & & & \\
\hline & ILI 3 & 0.92 & & & \\
\hline & ILI 4 & 0.93 & & & \\
\hline \multirow[t]{5}{*}{ F2 - Advancement } & & & 0.93 & 0.87 & 0.62 \\
\hline & ILI 5 & 0.9 & & & \\
\hline & ILI 6 & 0.88 & & & \\
\hline & ILI 7 & 0.86 & & & \\
\hline & ILI 8 & 0.88 & & & \\
\hline \multirow[t]{5}{*}{ F3 - Entrepreneurship } & & & 0.95 & 0.89 & 0.68 \\
\hline & ILI 9 & 0.93 & & & \\
\hline & ILI10 & 0.95 & & & \\
\hline & ILI11 & 0.94 & & & \\
\hline & ILI12 & 0.82 & & & \\
\hline \multirow[t]{4}{*}{ F4-Impresarioship } & & & 0.92 & 0.84 & 0.63 \\
\hline & ILI13 & 0.89 & & & \\
\hline & ILI14 & 0.91 & & & \\
\hline & ILI15 & 0.87 & & & \\
\hline Global ILI (15 items) & & & 0.98 & 0.97 & 0.65 \\
\hline
\end{tabular}

\section{Predictive validity}

The correlations we obtained among ILI dimensions and employee variables (positive and negative affect at work, as well as work engagement) provide initial support for the validity of the ILI (Table 4). In line with H2, ILI facets were positively related to work engagement and positive affect at work. At the same time, all these variables were negatively related to negative affect, with correlations ranging in absolute size between 0.29 and 0.61. Participants' key demographic variables were largely unrelated to the study's variables. However, participant age, supervisor age, and time working with the same team presented some significant low negative correlations with the global ILI measure, several ILI facets and positive affect. Time working with the supervisor and time working with the team was slightly related to negative affect. None of the demographic variables was associated with work engagement.
Table 4

Descriptive statistics and Pearson's correlations among study variables

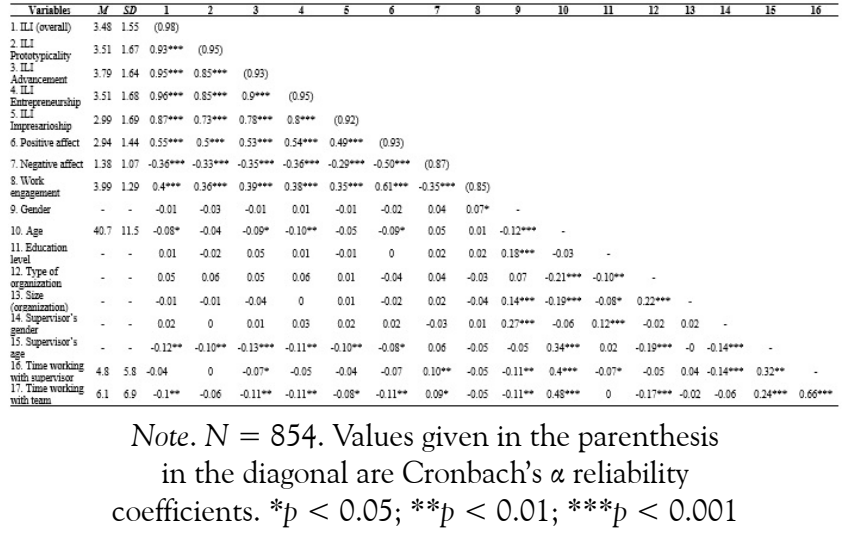

In order to more deeply explore the relationships among ILI dimensions and employees' job-related affect and work engagement, we tested the model proposed in Figure 1. The fit indices for this model were adequate $(\mathrm{CFI}=0.93$, NNFI $=0.92$, and RMSEA $=0.07)$, except for chi-square (S$\left.\mathrm{B} \chi^{2}(389)=2026.10, p<0.001\right)$. Regarding the relationship among variables, only identity entrepreneurship was directly and significantly related to positive and negative affect, both of which were significantly related to employees' work engagement in the hypothesized directions. In particular, employees reported greater positive affect and lowered negative affect due to their increased perception of leaders' identity entrepreneurship. Regarding the significance and relevance of the relationships in the model, positive affect had a stronger direct link to work engagement than negative affect $(\beta=$ $0.69, p<0.001$ and $\beta=-0.12, p<$ 0.001 , respectively). Moreover, the percentages of variance explained were $52.9 \%$ for work engagement, $35 \%$ for positive affect, and $17.1 \%$ for negative affect; the fact that they were all greater than the recommended cut-off value of 10\% (Falk \& Miller, 1992) substantiated the model's predictive validity. 


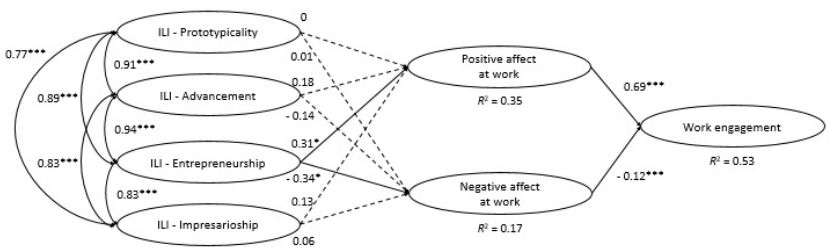

Figure 1

Relationship between identity leadership and followers' work engagement as mediated by positive and negative job-related affect

\section{Discussion}

We designed this study to validate the ILI in Spanish organizational settings and examine each dimension's relationship with employees' work engagement and job-related affect. We made some minor changes to the version validated in Chile (van Dick et al., 2018) to adapt it to more common linguistic expressions in Spain. From a psychometric standpoint, and supporting $\mathrm{H} 1$, our results indicate that the Spanish version of the ILI presents the same factorial structure as the original one (Steffens, Haslam, Reicher, et al., 2014); specifically, it is composed of four factors, namely identity prototypicality, identity advancement, identity entrepreneurship, and identity impresarioship. According to the social identity approach to leadership (van Dick \& Kerschreiter, 2016; van Dick \& Monzani, 2020), leaders should not only embody their group's social identity (identity prototypicality), but they should also act according to it in the interest of the group (identity advancement), actively shape it (identity entrepreneurship), and make it "come alive" for group members (identity impresarioship). In line with van Dick et al. (2018), a four-correlated factors model (Model 1) and a model in which four first-order factors contribute to a higher-order construct of identity leadership (Model 3) fit the data well. All factors showed satisfactory internal consistency and adequate convergent validity. Therefore, we may conclude that the Spanish version of the ILI is a valid, reliable tool to measure identity leadership in Spanish-speaking populations. Nonetheless, we encourage researchers in other Spanish- speaking countries to review the wording of items to facilitate participants' understanding.

From a practical point of view, our empirical study shows that identity leadership facets were positively related to work engagement among employees, with correlations ranging between 0.35 and 0.39. In addition, as expected, all four facets were positively related to positive affect (with correlations between 0.49 and $0.55)$ and negatively related to negative affect (with correlations between -0.29 and -0.36). Furthermore, higher levels of positive affect were associated with higher levels of work engagement, while higher levels of negative affect were associated with lower levels of work engagement. However, only identity entrepreneurship was significantly related to work engagement as mediated by affect in our model. These results support those obtained by Steffens, Haslam, Kerschreiter, et al. (2014) and Steffens, Haslam, Reicher, et al. (2014). However, they fail to support the relevance of identity impresarioship found by the latter. Notably, also in line with Steffens, Haslam, Reicher, et al. (2014), they demonstrate the importance of considering the ILI's four different facets separately, rather than in terms of a single higher-order factor: despite the high correlations obtained among facets $(0.73$ to 0.90 according to this study, 0.77 to 0.87 according to van Dick et al., 2018, and 0.78 to 0.88 in organizational settings according to Steffens, Haslam, Reicher et al., 2014) each facet has a unique impact on organizational and employee outcomes such as work engagement. Thus, we second Steffens, Haslam, Reicher, et al. (2014) in recommending consideration of the ILI in terms of its four separate facets rather than a single, higher-order identity leadership factor. Our proposed version allows for a deeper understanding of each dimension's contributions to the leadership process and relevance as a predictor of organizational and employee outcomes. 


\section{Implications}

From a theoretical point of view, our study adds support to the cross-cultural factorial structure of the ILI and each facet's unique contributions. As both leaders and followers are members of the same entity, they are linked together within a collective identity group (Epitropaki et al., 2017). According to Epitropaki et al. (2017), despite the wealth of papers on leadership and emotion published in recent years, there is a striking lack of studies on leader identity and emotion. We have attempted to address this gap by examining the role of emotion in leadership and followership identity. In so doing, we have contributed to the understanding of leaders' capacity to promote employees' job-related positive affect and reduce their negative affect, both of which relate to work engagement. We have proposed affect as a possible explanatory mechanism by which identity leadership can relate to employees' wellbeing.

Our results also provide insight into how to foster work engagement in organizations. Work engagement should be promoted, as it is a robust predictor of performance and other relevant organizational outcomes (Borst et al., 2020; Robledo et al., 2019). Our findings suggest that leaders can promote positive affect and reduce negative affect, by actively shaping their group's social identity, thus increasing employees' work engagement.

From a practical perspective, the availability of a validated instrument in Spanish allows practitioners to measure identity leadership in organizations. In addition, the ILI can be used to not only assess but also develop leadership (van Dick et al., 2018). We suggest that managers be trained in leadership identity to enhance their knowledge and adoption of identity prototypicality, identity advancement, identity entrepreneurship, and identity impresarioship, all of which are positively associated with desirable outcomes in their followers. In particular, the ILI (with its corresponding adaptations) may be useful in assessing managers' motivation and ability to promote leadership within the
5R leadership development program (based on Readying, Reflecting, Representing, Realizing, and Reporting) proposed by Haslam et al. (2017).

Limitations and recommendations for future research

Some of our study's limitations should be taken into account. First and foremost, its cross-sectional design does not allow for causal interpretations. Although our results show that social identity entrepreneurship is associated with positive and negative affect and work engagement, increased perception of affect and identity entrepreneurship could be both a consequence of work engagement and a cause. We theoretically established our hypotheses based on previous studies, but further experimental and longitudinal research is needed to confirm causality. Second, participants were not members of a single team or organization. Different types of organizations may foster cultures that in turn promote (or hinder) work engagement. Managers' training in different aspects of leadership may also vary significantly across organizations. Third, all measures were self-reported, and therefore social desirability cannot be discarded, although we ensured anonymity to reduce this possibility. Fourth, we measured identity leadership by measuring employees' perceptions of their immediate managers. Future studies should analyze to what extent managers' perceptions of their identity management coincide with those of their followers.

\section{Conclusions}

Our study's results, based on a sample of 854 employees, indicate that the Spanish version of the ILI has satisfactory factorial validity and internal consistency, thus replicating the original inventory's four-factor structure. Regarding criterion validity, results suggest that different facets of the ILI have a unique impact on organizational and employee outcomes. According to our study, only identity 
entrepreneurship is significantly related to work engagement mediated by job-related affect. Thus, a multidimensional approach to the ILI appears to be useful in better understanding how identity leadership relates to relevant organizational outcomes.

\section{References}

Arnold, K. A. (2017). Transformational leadership and employee psychological well-being: A review and directions for future research. Journal of Occupational Health Psychology, 22 (3), 381-393. https://d oi.org/10.1037/ocp0000062

Azanza, G., Gorgievski, M. J., Moriano, J. A., \& Molero, F. (2018). Influencing salespeople's work outcomes through authentic leadership. Leadership $\mathfrak{B}$ Organization Development Journal, 39(7), 926-944. https://doi.org/10.1108/LODJ-05 $-2017-0113$

Bentler, P. M. (2006). EQS 6 Structural Equations Program manual. Multivariate Software, Inc.

Bentler, P. M., \& Wu, E. J. (2015). Supplement to EQS 6.3 for Windows User's Guide. Multivariate Software, Inc.

Bledow, R., Schmitt, A., Frese, M., \& Kühnel, J. (2011). The affective shift model of work engagement. Journal of Applied Psychology, 96(6), 1246-1257. https://doi.org/10.1037/ a0024532

Borst, R. T., Kruyen, P. M., Lako, C. J., \& de Vries, M. S. (2020). The attitudinal, behavioral, and performance outcomes of work engagement: A comparative metaanalysis across the public, semipublic, and private sector. Review of Public Personnel Administration, 40(4), 613-640. https://doi. org/10.1177/0734371X19840399

Brown, T. A. (2015). Confirmatory factor analysis for applied research (2 ${ }^{\mathrm{a}}$ ed.). Guilford Press.

Castellano, E., Muñoz-Navarro, R., Toledo, M. S., Spontón, C., \& Medrano, L. A. (2019). Cognitive processes of emotional regulation, burnout and work engagement.
Psicothema, 31 (1), 73-80. https://doi.org/10 $.7334 /$ psicothema2018.228

Epitropaki, O., Kark, R., Mainemelis, C., \& Lord, R. G. (2017). Leadership and followership identity processes: A multilevel review. The Leadership Quarterly, 28(1), 104-129. https: //doi.org/10.1016/j.leaqua.2016.10.003

Falk, R. F., \& Miller, N. B. (1992). A primer for soft modeling. The University of Akron Press.

Fornell, C. G., \& Larcker, D. F. (1981). Evaluating structural equation models with unobservable variables and measurement error. Journal of Marketing Research, 18(1), 39-50. https://doi.org/10.2307/3151312

Hair, J. F., Black, W. C., Babin, B. J., Anderson, R. E., \& Tatham, R. L. (2006). Multivariate data analysis (6th ed.). Pearson Prentice Hall.

Haslam, S. A., Steffens, N. K., Peters, K., Boyce, R. A., Mallett, C. J., \& Fransen, K. (2017). A social identity approach to leadership development. Journal of Personnel Psychology, 16(3), 113-124. https: //doi.org/10.1027/1866-5888/a000176

Haslam, S. A., \& van Dick, R. (2012). A social identity approach to workplace stress. In D. D. Cremer, R. V. Dick \& K. Murnighan (Eds.), Social psychology and organizations (pp. 325-352). Routledge.

Hogg, M. A., Abrams, D., Otten, S., \& Hinkle, S. (2004). The social identity perspective: Intergroup relations, self-conception, and small groups. Small Group Research, 35(3), 246-276. https://doi.org/10.1177/10464964 04263424

Laguna, M., Mielniczuk, E., Razmus, W., Moriano, J. A., \& Gorgievski, M. J. (2017). Cross-culture and gender invariance of the Warr (1990) job-related well-being measure. Journal of Occupational and Organizational Psychology, 90 (1), 117-125. h ttps://doi.org/10.1111/joop.12166

Molero, F., Mikulincer, M., Shaver, P. R., Laguía, A., \& Moriano, J. A. (2019). The development and validation of the leader as security provider scale. Journal of Work and Organizational Psychology, 35(3), 183-193. h ttps://doi.org/10.5093/jwop2019a20 
Platow, M. J., Haslam, S. A., Reicher, S. D., \& Steffens, N. K. (2015). There is no leadership if no-one follows: Why leadership is necessarily a group process. International Coaching Psychology Review, 10(1), 20-37.

Robledo, E., Zappalà, S., \& Topa, G. (2019). Job crafting as a mediator between work engagement and wellbeing outcomes: A time-lagged study. International Journal of Environmental Research and public Health, 16(8), 1376. https://doi.org/10.3390/ijerph 16081376

Schaufeli, W. B., Shimazu, A., Hakanen, J., Salanova, M., \& De Witte, H. (2017). An ultra-short measure for work engagement: The UWES-3 validation across five countries. European Journal of Psychological Assessment, 35(4), 577-591. https://doi.org/ 10.1027/1015-5759/a000430

Skakon, J., Nielsen, K., Borg, V., \& Guzman, J. (2010). Are leaders' well-being, behaviours and style associated with the affective wellbeing of their employees? A systematic review of three decades of research. Work $\mathbb{E}$ Stress, 24(2), 107-139. https://doi.org/10.10 80/02678373.2010.495262

Steffens, N. K., Haslam, S. A., Kerschreiter, R., Schuh, S. C., \& van Dick, R. (2014). Leaders enhance group members' work engagement and reduce their burnout by crafting social identity. Zeitschrift für Personalforschung, 28(1-2), 173-194. https:/ /doi.org/10.1688/ZfP-2014-01-Steffens

Steffens, N. K., Haslam, S. A., Reicher, S. D., Platow, M. J., Fransen, K., Yang, J., Ryan, M. K., Jetten, J., Peters, K., \& Boen, F. (2014). Leadership as social identity management: Introducing the Identity Leadership Inventory (ILI) to assess and validate a four-dimensional model. The Leadership Quarterly, 25(5), 1001-1024. htt ps://doi.org/10.1016/j.leaqua.2014.05.002

Steffens, N. K., Haslam, S. A., Ryan, M. K., \& Kessler, T. (2013). Leader performance and prototypicality: Their inter-relationship and impact on leaders' identity entrepreneurship. European Journal of Social Psychology, 43(7), 606-613. https:// doi.org/10.1002/ejsp.1985

Steffens, N. K., Haslam, S. A., Schuh, S. C., Jetten, J., \& van Dick, R. (2017). A meta-analytic review of social identification and health in organizational contexts. Personality and Social Psychology Review, 21 (4), 303-335. https://doi.org/10.1177/10 88868316656701

Steffens, N. K., Munt, K. A., van Knippenberg, D., Platow, M. J., \& Haslam, S. A. (2020). Advancing the social identity theory of leadership: A meta-analytic review of leader group prototypicality. Organizational Psychology Review, 11(1), 35-72. https://doi. org/10.1177/2041386620962569

Steffens, N. K., Yang, J., Jetten, J., Haslam, S. A., \& Lipponen, J. (2018). The unfolding impact of leader identity entrepreneurship on burnout, work engagement, and turnover intentions. Journal of Occupational Health Psychology, 23(3), 373-387. https://d oi.org/10.1037/ocp0000090

Tajfel, H., \& Turner, J. C. (1979). An integrative theory of intergroup conflict. In W. G. Austin \& S. Worchel (Eds.), The social psychology of intergroup relations (pp. 33-47). Brooks Cole Publishing.

Turner, J. C., Hogg, M. A., Oakes, P. J., Reicher, S. D., \& Wetherell, M. S. (1987). Rediscovering the social group: A self-categorization theory. Blackwell.

van Dick, R., \& Kerschreiter, R. (2016). The social identity approach to effective leadership: An overview and some ideas on cross-cultural generalizability. Frontiers of Business Research in China, 10(3), 363-384. https://doi.org/10.3868/s070-005016-0013-3

van Dick, R., Lemoine, J. E., Steffens, N. K., Kerschreiter, R., Akfirat, S. A., Avanzi, L., Avanzi, L., Dumont, K., Epitropaki, O., Fransen, K., Giessner, S., González, R., Kark, R., Lipponen, J., Markovits, Y., Monzani, L., Orosz, G., Pandey, D., RolandLévy, C., . . . Haslam, S. A. (2018). Identity leadership going global: Validation of the Identity Leadership Inventory across 
Identity Leadership and Work Engagement in Spain: A Cross-Cultural Adaptation of the Identity...

20 countries. Journal of Occupational and Organizational Psychology, 91 (4), 697-728. h ttps://doi.org/10.1111/joop.12223

van Dick, R., \& Monzani, L. (2020). Positive leadership in organizations. Oxford Research Encyclopedia of Psychology.

Villajos, A., García-Ael, C., \& Topa, G. (2019). Job crafting among labor union representatives: Its impact on work engagement and job satisfaction. Social Sciences, 8(1), 2-11. https://doi.org/10.3390 /socsci8010020

Zhou, J., Ma, Y., Cheng, W., \& Xia, B. (2014). Mediating role of employee emotions in the relationship between authentic leadership and employee innovation. Social Behavior and Personality: an international journal, 42 (8), 1267-1278. https://doi.org/10.2224/s bp.2014.42.8.1267

\section{Notes}

* Research article. 